\title{
Stock Price Valuation Using The Dividend Discount Model on IDX Mining Period 2011-2020
}

\author{
Dinda Febriani ${ }^{1}$, Marieska Lupikawaty ${ }^{1, *}$, Al Hushori $^{2}$, Haris Wilianto ${ }^{2}$, \\ Muhammad Ridallah ${ }^{1}$, Muhammad Faris Salman ${ }^{2}$ \\ ${ }^{1}$ Applied Undergraduate Study Program, Department of Business Administration, Sriwijaya State Polytechnic \\ ${ }^{2}$ Business Administration Diploma Study Program, Department of Business Administration, Sriwijaya State \\ ${ }^{*}$ Corresponding author. E-mail:marieska@polsri.ac.id
}

Polytechnic

\begin{abstract}
Investors can take stock valuations to minimize investment risk. The study aims i) to know the intrinsic value of IDX Mining stock from 2011-2020, ii) identify whether the stock is considered undervalued, correctly valued, or overvalued. and iii) make the right investment decisions based on their conditions The research method uses the dividend discount model. Purposive sampling was used in sampling, so the sample was of 3 companies, namely ADRO, ITMG, and PTBA. Stock valuations provide intrinsic value, which will be used to determine whether the stock is undervalued or correctly valued, or overvalued. Undervalued is a condition when the intrinsic value is higher than the stock price then correctly valued is a condition when the intrinsic value is the same as with the stock price, while overvalued is condition when the intrinsic value is lower than the stock price.
\end{abstract}

\section{Keywords: Dividend Discount Model, Stock Price Valuation.}

\section{INTRODUCTION}

Capital markets can be attached where the meeting of parties who need funds with parties who need the means to invest. Parties who need funds will first register with the authority that oversees the capital market, after going beyond a series of initial public offering (IPO) stages then the party can offer its securities.

Capital markets as one of the means to invest are currently very popular. Financial products available include mutual funds, bonds, stocks and ETFs. Stocks are more often chosen compared to other products, as they provide great returns. But with the return is also accompanied by appropriate risks as well.

One of the things that investors should consider when making investment decisions is fluctuating stock prices, stock prices are very vulnerable to being affected by several things, for example, positive or negative news on an issuer, state economic conditions, and government policies. One example of the vulnerability of stock price changes is since the corona virus in Indonesia in early 2020.

In 2020 the capital market in Indonesia experienced a market crash, almost all stocks experienced a significant price decline, however the capital market in Indonesia was able to survive and get through this period. Based on data obtained from the website [1], one of the drivers of the increase in the composite stock price index was due to the increase in the mining sector, which shot up more than twice as much as other sectoral indices. Therefore, it indirectly shows that there is high investor interest in the industry.

With this significant increase, it is feared that investors will choose stocks to just follow the upward trend without considering and conducting an analysis first. One form of analysis that can be used is stock valuation, where stock valuation will provide intrinsic value. Intrinsic value is the expected value, and is used as a guide to assess fair prices [2]. Intrinsic value helps investors identify whether a stock is undervalued, or correctly valued or overvalued, so they can make investment decisions based on that.

Dividend discount model used as a stock price valuation method. The dividend discount model is an analysis that relates all the expected cash flows from paying dividends to the company's shares [3].

Knowing the condition of a mining company's stock and making the right decision based on its condition is the aim of the study. This study uses financial data from 
the last 10 years of mining companies, with the aim that the results obtained are more relevant and accurate.

\section{LITERATURE STUDY}

\subsection{Stock}

Stock are are certificates of ownership that the owner can use to acquire a portion of the company's assets[10]. Shares can be interpreted as securities in the company's ownership mode. Capital gains and dividends are the profits that will be earned by investors in investing in stocks. Capital gains are the profit from the sale of shares at a higher price than the purchase price, while dividends are corporate profits distributed to investors.

\subsection{Stock Price Appraisal}

Stock valuation is one of the investor's efforts to avoid things that are not liked. Intrinsic value, book value and market value are values that will be found in stock valuationas quoted from Tandelilin in [4]. Stock valuation in this study uses intrinsic value and stock prices to be compared to determine the condition of the stock. The following is a guideline to find out the condition of the stock

Table 1 Stock Price Valuation

\begin{tabular}{|l|l|}
\hline \multicolumn{1}{|c|}{ Comparison } & \multicolumn{1}{c|}{ Condition } \\
Intrinsic Value $>$ & $\begin{array}{l}\text { Low stock price } \\
\text { (undervalued) }\end{array}$ \\
\hline $\begin{array}{l}\text { Intrinsic Value }< \\
\text { Market Price }\end{array}$ & $\begin{array}{l}\text { Stock price is } \\
\text { expensive (overvalued) }\end{array}$ \\
\hline $\begin{array}{l}\text { Intrinsic Value }= \\
\text { Market Price }\end{array}$ & $\begin{array}{l}\text { Fair or normal share } \\
\text { price (correctly value) }\end{array}$ \\
\hline
\end{tabular}

Source: [5]

Based on Table 1, It is known that there are three conditions in the valuation of a stock, the first condition is undervalue or cheap, namely when the intrinsic value is greater than the market price, then overvalued or expensive which is a condition where the intrinsic value is smaller than the market price, the last correctly value or fair price is a condition where the intrinsic value is equal to the market price, after knowing these conditions, the investment decision on the design of its shares is:

1. if undervalued investment decision is shares buying shares

2. if overvalued the investment decision is to sell the shares

3. if correctly the value of the investment decision is to hold the stock

\subsection{Dividend Discount Model . Method}

The discounted dividend approach model is one that is included in the company's basic analysis implemented by linking expected cash flow with dividends. Dividend discount model is a model that in determining the estimated stock price will discount the entire flow of dividends that will be received in the future [3].

Rate of return expected, annual dividends and dividend growth are factors that affect stock prices[6]. The Dividend Discount Model uses dividends as the basis for its estimation, because dividends are one of the reasons investors make decisions [7]. Dividends are profits distributed by the company, with the amount of the distribution depending on each company's policy [8].

\section{RESEARCH METHOD}

This study uses a quantitative descriptive method, where the population is Mining Sector IDX index as many as 47 companies. Purposive sampling is used in research, with the following provisions:

1. Companies listed in the IDX Mining Sector during the period 2011-2020.

2. Companies that regularly issue financial statements and pay dividends from 2011 to 2020, where dividends are the reason for investors to invest.

Based on these provisions, a sample of 3 companies was obtained, namely ADRO, ITMG and PTBA.

Table 2 Research Sample

\begin{tabular}{|l|l|l|}
\hline No & Code & Company name \\
\hline 1 & ADRO & PT Adaro Energy Tbk \\
\hline 2 & ITMG & $\begin{array}{l}\text { PT Indo Tambang Raya } \\
\text { Megah Tbk }\end{array}$ \\
\hline 3 & PTBA & PT Bukit Asam Tbk \\
\hline
\end{tabular}

\subsection{Data Analysis Techniques}

The steps to analyze the dividend discount model method are:

1. Calculating financial ratios
a. Return on equity
b. Earnings per share
c. Dividend per share
d. Dividend payout ratio

2. Calculating dividend growth rate $(\mathrm{g})$

$$
g=\text { ROE } x \text { Retention Rate }
$$

Where retention rate $=1-\mathrm{DPR}$

3. Counting levels expected return $(\mathrm{k})$

4. Calculatıng the estımated expected dividend

$$
k=\frac{\text { Do }}{\text { Po }}+g
$$

$$
\mathrm{Dt}=\mathrm{D} 0(1+\mathrm{g})
$$


5. Calculation of the intrinsic value of the dividend discount model

$$
\boldsymbol{P}=\frac{\mathrm{D}_{\mathrm{t}}}{\mathrm{k}-\mathrm{g}}
$$

6. Making investment decisions.

\section{RESULTS AND DISCUSSION}

The dividend discount model method will produce intrinsic value. Furthermore, to determine stock conditions and investment decisions, is to compare the intrinsic value with the company's stock price, the company's stock price is obtained through the website [9], In performing the necessary calculations of the company's financial statements, the following is the financial ratio information taken from the company's financial statements:

Table 3 Financial Statements

\begin{tabular}{|c|c|c|c|c|c|}
\hline \multirow[b]{2}{*}{ Tahun } & & & & & \\
\hline & $\begin{array}{l}\text { Kode } \\
\text { Saham }\end{array}$ & ROE & EPS & DPS & DPR \\
\hline \multirow{3}{*}{2011} & ADRO & $23 \%$ & Rp 157 & $\mathrm{Rp}$ & $48 \%$ \\
\hline & ITMG & $51 \%$ & Rp 4.383 & Rp 3.674 & $84 \%$ \\
\hline & PTBA & $38 \%$ & $\operatorname{Rp} 1.340$ & Rp 804 & $60 \%$ \\
\hline \multirow{3}{*}{2012} & ADRO & $13 \%$ & $\mathrm{Rp} \quad 116$ & $\mathrm{Rp}$ & $30 \%$ \\
\hline & ITMG & $43 \%$ & Rp 3.697 & Rp 3.130 & $85 \%$ \\
\hline & PTBA & $34 \%$ & Rp 1.263 & Rp 692 & $55 \%$ \\
\hline \multirow{3}{*}{2013} & ADRO & $7 \%$ & $\mathrm{Rp} \quad 88$ & $\mathrm{Rp}$ & $32 \%$ \\
\hline & ITMG & $23 \%$ & Rp 2.211 & Rp 1.989 & $90 \%$ \\
\hline & PTBA & $25 \%$ & $\mathrm{Rp} 805$ & $\mathrm{Rp} \quad 436$ & $54 \%$ \\
\hline \multirow{3}{*}{2014} & ADRO & $6 \%$ & $\begin{array}{ll}\mathrm{Rp} & 71 \\
\end{array}$ & $\mathrm{Rp} \quad 30$ & $42 \%$ \\
\hline & ITMG & $23 \%$ & Rp 2.213 & Rp 1.745 & $79 \%$ \\
\hline & PTBA & $22 \%$ & Rp 809 & Rp 306 & $38 \%$ \\
\hline \multirow{3}{*}{2015} & ADRO & $5 \%$ & Rp 65 & $\mathrm{Rp}$ & $49 \%$ \\
\hline & ITMG & $8 \%$ & Rp 770 & Rp 813 & $105 \%$ \\
\hline & PTBA & $22 \%$ & Rp 884 & 265 & $30 \%$ \\
\hline \multirow{3}{*}{2016} & ADRO & $9 \%$ & Rp 143 & $\mathrm{Rp}$ & $30 \%$ \\
\hline & ITMG & $14 \%$ & $\operatorname{Rp} 1.554$ & Rp 1.531 & $98 \%$ \\
\hline & PTBA & $19 \%$ & Rp 879 & Rp 261 & $30 \%$ \\
\hline \multirow{3}{*}{2017} & ADRO & $13 \%$ & Rp 227 & Rp 108 & $47 \%$ \\
\hline & ITMG & $26 \%$ & Rp 3.029 & Rp 3.102 & $102 \%$ \\
\hline & PTBA & $33 \%$ & Rp 395 & $\mathrm{Rp} \quad 291$ & $74 \%$ \\
\hline
\end{tabular}

\begin{tabular}{|c|l|l|l|l|lr|r|}
\hline \multirow{3}{*}{2018} & ADRO & $11 \%$ & Rp & 216 & $\mathrm{Rp}$ & 90 & $42 \%$ \\
\cline { 2 - 8 } & ITMG & $27 \%$ & $\mathrm{Rp}$ & 3.316 & $\mathrm{Rp}$ & 3.363 & $101 \%$ \\
\cline { 2 - 8 } & PTBA & $31 \%$ & $\mathrm{Rp}$ & 445 & $\mathrm{Rp}$ & 327 & $74 \%$ \\
\hline \multirow{3}{*}{2019} & ADRO & $11 \%$ & $\mathrm{Rp}$ & 189 & $\mathrm{Rp}$ & 122 & $64 \%$ \\
\cline { 2 - 8 } & ITMG & $14 \%$ & $\mathrm{Rp}$ & 1.556 & $\mathrm{Rp}$ & 1.237 & $80 \%$ \\
\cline { 2 - 7 } & PTBA & $22 \%$ & $\mathrm{Rp}$ & 351 & $\mathrm{Rp}$ & 317 & $90 \%$ \\
\hline \multirow{3}{*}{2020} & ADRO & $4 \%$ & $\mathrm{Rp}$ & 70 & $\mathrm{Rp}$ & 66 & $95 \%$ \\
\cline { 2 - 7 } & ITMG & $4 \%$ & $\mathrm{Rp}$ & 472 & $\mathrm{Rp}$ & 459 & $97 \%$ \\
\cline { 2 - 7 } & PTBA & $14 \%$ & $\mathrm{Rp}$ & 209 & $\mathrm{Rp}$ & 73 & $35 \%$ \\
\hline
\end{tabular}

Once the company's financial ratio is known, the next is the calculation of the expected dividend growth rate $(\mathrm{g})$, the expected rate of return $(\mathrm{K})$, the expected dividend estimate (Dt) and intrinsic value (P). As for the results as follows:

Table 4 Calculation Results $\mathrm{g}, \mathrm{K}, \mathrm{Dt}$ and Intirinsic Values (P)

\begin{tabular}{|c|c|c|c|c|c|}
\hline Tahun & $\begin{array}{l}\text { Kode } \\
\text { Saham }\end{array}$ & G & K & Dt & $\mathbf{P}$ \\
\hline \multirow{3}{*}{2011} & ADRO & 0,118 & 0,1 & $\mathrm{Rp}$ & Rp 1.978 \\
\hline & ITMG & 0,082 & 0,1 & $\operatorname{Rp} 1.300$ & Rp 41.809 \\
\hline & PTBA & 0,151 & 0,3 & Rp 602 & Rp 3.996 \\
\hline \multirow{3}{*}{2012} & ADRO & 0,089 & 0,1 & $\begin{array}{ll}\mathrm{Rp} \quad 82 \\
\end{array}$ & $\begin{array}{ll}\mathrm{Rp} & 1.732 \\
\end{array}$ \\
\hline & ITMG & 0,066 & 0,2 & Rp 3.917 & Rp 44.298 \\
\hline & PTBA & 0,155 & 0,4 & Rp 928 & Rp 3.487 \\
\hline \multirow{3}{*}{2013} & ADRO & 0,050 & 0,1 & Rp 37 & Rp 1.144 \\
\hline & ITMG & 0,023 & 0,1 & Rp 3.202 & Rp 29.153 \\
\hline & PTBA & 0,112 & 0,5 & Rp 770 & Rp 2.269 \\
\hline \multirow{3}{*}{2014} & ADRO & & 0,1 & Rp 29 & Rp 1.074 \\
\hline & ITMG & 0,048 & 0,2 & Rp 2.084 & Rp 16.113 \\
\hline & PTBA & 0,136 & 0,3 & Rp 495 & Rp $\quad 2.840$ \\
\hline \multirow{3}{*}{2015} & ADRO & 0,023 & 0,1 & $\mathrm{Rp}$ & 527 \\
\hline & ITMG & $-0,004$ & 0,3 & Rp 1.738 & Rp 5.701 \\
\hline & PTBA & 0,154 & 0,5 & Rp 353 & $\mathrm{Rp} \quad 1.044$ \\
\hline \multirow{3}{*}{2016} & ADRO & 0,063 & 0,1 & Rp 34 & Rp 1.802 \\
\hline & ITMG & 0,002 & 0,1 & Rp 814 & Rp 16.912 \\
\hline & PTBA & 0,135 & 0,2 & Rp 301 & Rp 2.837 \\
\hline \multirow{3}{*}{2017} & ADRO & 0,069 & 0,1 & $\mathrm{Rp}$ & Rp 1.988 \\
\hline & ITMG & $-0,006$ & 0,1 & Rp 1.521 & Rp 20.569 \\
\hline & PTBA & 0,086 & 0,1 & $\mathrm{Rp}$ & Rp 2.672 \\
\hline \multirow{3}{*}{2018} & ADRO & 0,065 & 0,2 & Rp 115 & Rp 1.294 \\
\hline & ITMG & $-0,004$ & 0,1 & Rp 3.090 & Rp 20.174 \\
\hline & PTBA & 0,083 & 0,2 & Rp 316 & Rp 4.658 \\
\hline
\end{tabular}




\begin{tabular}{|c|c|c|c|c|c|}
\hline \multirow{3}{*}{2019} & ADRO & 0,039 & 0,1 & $\mathrm{Rp}$ & $\mathrm{Rp} \quad 1.616$ \\
\hline & ITMG & 0,029 & 0,3 & Rp 3.461 & Rp 11.811 \\
\hline & PTBA & 0,021 & 0,1 & 334 & Rp 2.716 \\
\hline \multirow{3}{*}{2020} & ADRO & 0,002 & 0,1 & 122 & $\mathrm{Rp} \quad 1.433$ \\
\hline & ITMG & 0,001 & 0,1 & Rp 1.239 & Rp 13.867 \\
\hline & PTBA & 0,093 & 0,2 & 346 & Rp 3.071 \\
\hline
\end{tabular}

After knowing the intrinsic value (P) of each company during the period 2011-2020, it further compares the core value with the stock market price, while the results of the comparison are:

Table 5 ADRO 2011-2020

\begin{tabular}{|c|c|c|c|}
\hline \multicolumn{4}{|c|}{ PT Adaro Energy Tbk } \\
\hline Year & $\begin{array}{l}\text { Market } \\
\text { price }\end{array}$ & $\begin{array}{l}\text { Intrinsic } \\
\text { Value }\end{array}$ & Condition \\
\hline 2011 & Rp 1,770 & IDR 1,978 & Undervalued \\
\hline 2012 & $\operatorname{Rp} 1,590$ & Rp 1,732 & Undervalued \\
\hline 2013 & $\operatorname{Rp} 1,090$ & $\operatorname{Rp} 1.144$ & Undervalued \\
\hline 2014 & $\operatorname{Rp} 1,040$ & Rp 1,074 & Undervalued \\
\hline 2015 & IDR 515 & IDR 527 & Undervalued \\
\hline 2016 & Rp 1,695 & Rp 1,802 & Undervalued \\
\hline 2017 & $\operatorname{Rp} 1,860$ & Rp 1,988 & Undervalued \\
\hline 2018 & Rp 1,215 & Rp 1,294 & Undervalued \\
\hline 2019 & Rp 1,555 & Rp 1,616 & Undervalued \\
\hline 2020 & Rp 1,430 & Rp 1,433 & Undervalued \\
\hline
\end{tabular}

The comparison between the intrinsic value through the DDM method and the market price based on Table 3, it is known that the comparison between the intrinsic value through the DDM method and the market price shows the result that during 2011-2020 ADRO shares are in an undervalued condition or a condition where the intrinsic value is greater than the stock price.

Table 6 ITMG 2011-2020

\begin{tabular}{|c|c|c|c|}
\hline \multicolumn{4}{|c|}{ PT Indo Tambangraya Megah Tbk } \\
\hline Year & Market price & $\begin{array}{l}\text { Intrinsic } \\
\text { Value }\end{array}$ & Condition \\
\hline 2011 & IDR 38,650 & Rp 41.809 & Undervalued \\
\hline 2012 & $\operatorname{Rp} 41,550$ & $\operatorname{Rp} 44,298$ & Undervalued \\
\hline 2013 & IDR 28,500 & IDR 29,153 & Undervalued \\
\hline 2014 & Rp 15,375 & Rp 16,113 & Undervalued \\
\hline 2015 & IDR 5,725 & $\operatorname{Rp} 5,701$ & Overvalued \\
\hline 2016 & Rp 16,875 & Rp 16,912 & Undervalued \\
\hline 2017 & IDR 20,700 & $\operatorname{Rp} 20,569$ & Overvalued \\
\hline 2018 & $\operatorname{Rp} 20,250$ & $\operatorname{Rp} 20,174$ & Overvalued \\
\hline 2019 & $\operatorname{Rp} 11,475$ & $\operatorname{Rp} 11,811$ & Undervalued \\
\hline 2020 & $\operatorname{Rp} 13,850$ & $\operatorname{Rp} 13,867$ & Undervalued \\
\hline
\end{tabular}

The comparison between the intrinsic value through the DDM method and the market price based on Table 5, it is known that the comparison between the intrinsic value through the DDM method and the market price shows that during 2011-2020 ITMG shares were overall undervalued, although in 2015, 2017 and 2018 are overvalued.

Table 7 PTBA 2011-2020

\begin{tabular}{|c|c|c|c|}
\hline \multicolumn{4}{|c|}{ PT Bukit Asam Tbk } \\
\hline Year & $\begin{array}{l}\text { Market } \\
\text { price }\end{array}$ & $\begin{array}{l}\text { Intrinsic } \\
\text { Value }\end{array}$ & Condition \\
\hline 2011 & $\mathrm{Rp} 3,470$ & Rp 3.996 & Undervalued \\
\hline 2012 & IDR 3,020 & $\operatorname{Rp} 3,487$ & Undervalued \\
\hline 2013 & Rp 2,040 & Rp 2.269 & Undervalued \\
\hline 2014 & IDR 2,500 & Rp 2,840 & Undervalued \\
\hline 2015 & Rp 905 & $\mathrm{Rp} 1,044$ & Undervalued \\
\hline 2016 & IDR 2,500 & $\operatorname{Rp} 2,837$ & Undervalued \\
\hline 2017 & $\mathrm{Rp} 2,460$ & Rp 2,672 & Undervalued \\
\hline 2018 & IDR 4,300 & $\operatorname{Rp} 4.658$ & Undervalued \\
\hline 2019 & Rp 2.660 & IDR 2,716 & Undervalued \\
\hline 2020 & $\operatorname{Rp} 2,810$ & IDR 3,071 & Undervalued \\
\hline
\end{tabular}

The comparison between the intrinsic value through the DDM method and the market price based on Table 6, it is known that the comparison between the intrinsic value through the DDM method and the market price shows that during 2011-2020 PTBA shares showed that during 2011-2020 PTBA shares were undervalued.

\subsection{Investment Decision Making}

Table 8 Assessment of Stock Conditions

\begin{tabular}{|l|l|}
\hline Comparison & Condition \\
\hline $\begin{array}{l}\text { Intrinsic Value }> \\
\text { Market Price }\end{array}$ & $\begin{array}{l}\text { Low stock price } \\
\text { (undervalued) }\end{array}$ \\
\hline $\begin{array}{l}\text { Intrinsic Value }< \\
\text { Market Price }\end{array}$ & $\begin{array}{l}\text { Stock price is expensive } \\
\text { (overvalued) }\end{array}$ \\
\hline $\begin{array}{l}\text { Intrinsic Value }= \\
\text { Market Price }\end{array}$ & $\begin{array}{l}\text { Fair or normal share price } \\
\text { (correctly value) }\end{array}$ \\
\hline
\end{tabular}

Based on the dividend discount model method, the results show that ADRO, ITMG, and PTBA shares as a whole are undervalued, therefore the investment decision is to buy or hold shares, because ADRO, ITMG and PTBA shares are undervalued or cheap. The results of the calculation of intrinsic value according to the DDM method show that the intrinsic value is often close to the market price, in line with this in research [6] which states that the intrinsic value with the DDM method will tend to approach the market price. 


\section{CONCLUSION}

Stock valuation using the dividend discount model method. In this study, the results show that ADRO, ITMG and PTBA are undervalued so that they are feasible to buy or hold the stock in the hope that it will provide capital gains on their investment. generate intrinsic value that will tend to follow market prices.

\section{ACKNOWLEDGMENTS}

The writing team would like to thank the Sriwijaya State Polytechnic for providing research grants for the 2021 lecturers' collaboration scheme.

\section{REFERENCES}

[1] http;//www.cnbc.indonesia.com

[2] Happy, Bambang. 2017. Fundamental Financial Management. Yogyakarta : CV Budi Utama.

[3] Financial Services Authority. 2016. Higher Education Level Financial Literacy. Jakarta.

[4] Natalia, Dea et al. 2019. Stock Valuation Analysis Using the Dividend Discount Model, Price Earning Ratio and Price to Book Value for Investment Decisions. Scientific Journal of Management. Volumes: 17.

[5] Nuzula, Nila Firdausi and FerinaNurlaily. (2020). Fundamentals of Investment Management. UB Press.
[6] Hasanah, Resti Siti and Ellen Rusliati. 2017. Share Prices Using the Dividend Discount Model Method and Price To Book Value. Journal of Business and Management Research. Volume : 10

[7] Wijaya, Avitta Putri et al. 2015. Fundamental Analysis Using the Dividend Discount Model (DDM) Approach to Assess the Fairness of Stock Prices (Study on Cement Sub-Sector Companies Listed on the Indonesia Stock Exchange 2011-2013 Period). Journal of Business Administration Volume: 26

[8] Sunaryo, Deni. (2019). Investment and Portfolio Management Textbook. Serang: CV. Qiara Media Publisher

[9] http://www.duniainvestasi.com/bei

[10] Nugraha, Egananda septian and Sri Sulasmiyati. 2017. Analysis of the intrinsic value of shares with . relative valuation techniques (Study on Cigarette Sub-Sector Companies Listed on the Indonesia Stock Exchange 2013-2016). Journal of Business Administration. Volumes: 52. 